\title{
A review of Silurian discinoid brachiopods from Gotland, Sweden
}

\author{
MICHAL MERGL
}

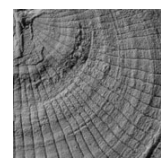

\begin{abstract}
Silurian discinoid brachiopods from Gotland currently housed in the Swedish Museum of Natural History in Stockholm are revised. Fourteen species of genera Schizocrania, Acrosaccus, Ivanothele, Orbiculoidea and Rugadiscina are described; three species (Acrosaccus barabackensis, A. hallaensis and Rugadiscina petesviki) are new. Although generic composition of the Gotland discinoid fauna is very similar to that of the Welsh Borderland rather than to that of the Barrandian in Bohemia, the species differences confirm a biogeographic separation of all these areas in the Silurian. - Key words: Brachiopoda, Discinida, taxonomy, Silurian, Gotland, Bohemia.
\end{abstract}

MERGL, M. 2010. A review of Silurian discinoid brachiopods from Gotland, Sweden. Bulletin of Geosciences 85(3), 367-384 (10 figures). Czech Geological Survey, Prague. ISSN 1214-1119. Manuscript received January 18, 2010; accepted in revised form June 18, 2010; published online September 2, 2010; issued September 30, 2010.

Michal Mergl, Department of Biology, Faculty of Education, University of West Bohemia at Plzeň, Klatovská 51, 30619 Plzeň, Czech Republic; mmergl@kbi.zcu.cz.

The island of Gotland is a classical area for investigation of Silurian fossiliferous successions. The richly fossiliferous strata have been collected for about 250 years, and many invertebrate groups have been revised, including rhynchonelliform brachiopods (see Bassett \& Cocks 1974, Copper 2004). Some of the specific brachiopod groups, mainly strophomenides, have been revised more recently (Musteikis \& Cocks 2004; Hoel 2005, 2007). Discinoid brachiopods, normally rare in the fossil record, have generally been overlooked.

The aim of this study is to revise the taxonomy of discinoid brachiopods from Gotland that are housed in the collections of the Swedish Museum of Natural History (Naturhistoriska riksmuseet) in Stockholm in order to update available data for future research of this brachiopod group. Revision of Silurian discinoid brachiopods from the Barrandian (Mergl 2001) and from classical British localities (Mergl 2006) provided a sound foundation for a critical review of the material from Gotland.

Published data concerning discinoids on Gotland are scarce, being restricted to affiliation of discinoid brachiopods to Orbiculoidea rugata (J. de C. Sowerby, 1839) or Orbiculoidea sp. (Hedström 1910, Hede 1921) or to formerly described British species Discina forbesi Davidson, 1848 (Lindström 1861). It is impossible to correlate species used by these authors in their fossil lists with any of the species recently described. Only Discina pilidium has been formally described from Gotland by Lindström (1861).

\section{Terminology}

Terminology follows the Treatise on Invertebrate Palaeontology, part H, Revised (Williams et al. 1997) but new terms "outer listrial plates" and "inner listrial plates" are introduced here. Outer listrial plates are laterally disposed, planar to steeply sloping sides of the listrium, formed by secondary shell and invariably covered by growth lines which continue from the adjacent surface of the postlarval shell. Inner listrial plates are undifferentiated deposits of secondary shell axially to outer listrial plates. Inner listrial plates often fill the pedicle slit and usually lack growth lines.

\section{Material}

The study is based on material of discinoid brachiopod from the island of Gotland reposited in the Swedish $\mathrm{Mu}-$ seum of Natural History (Naturhistoriska riksmuseet) at Stockholm. The collections are historical, with many specimens sampled in the $19^{\text {th }}$ and beginning of the $20^{\text {th }}$ century. Exact stratigraphical and locality data are often very general and insufficient to accurately correlate with current stratigraphy. Where possible, old data have been re-interpreted with regard to modern localities and age following Laufeld (1974). Interpretation of stratigraphic and locality data from specimens labels and corresponding species range are given in Figs 1 and 2. 


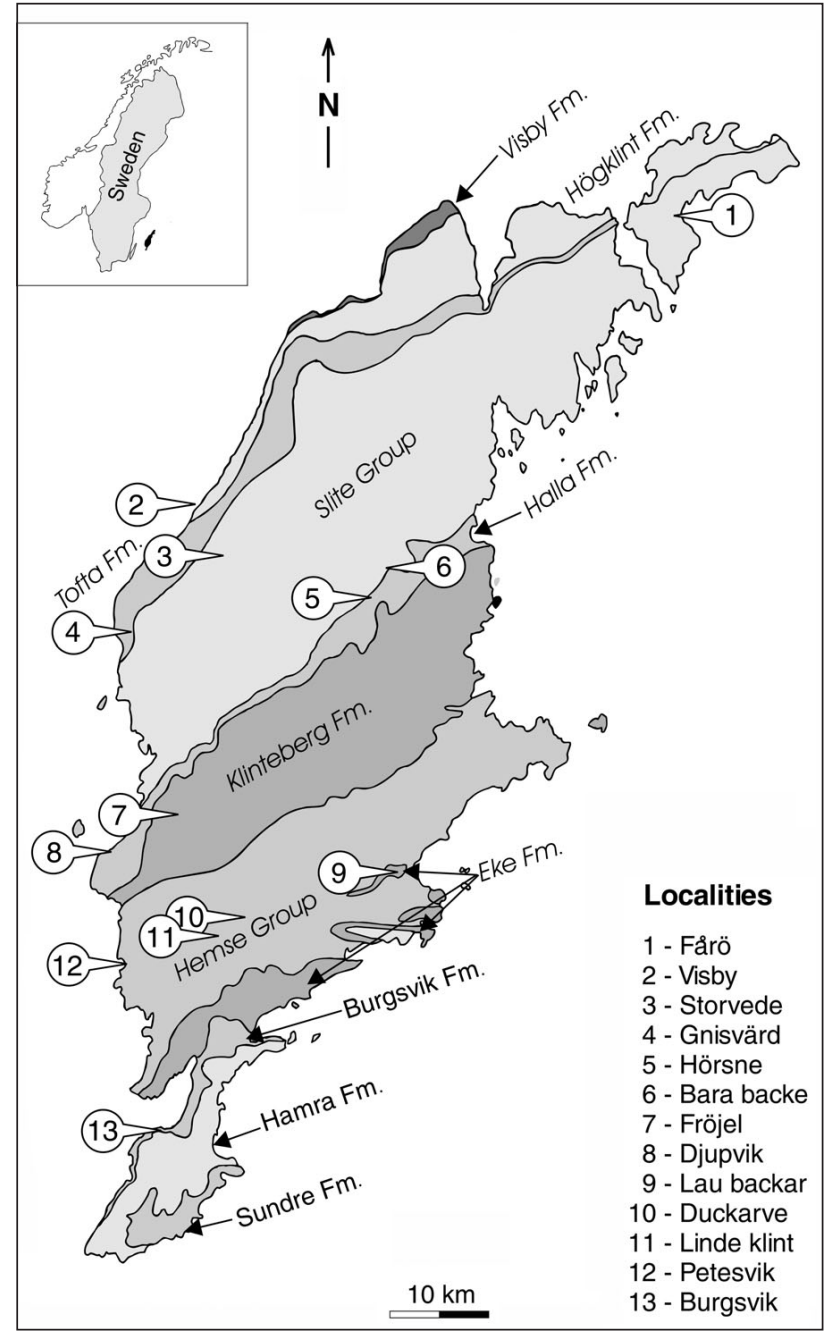

Figure 1. Geology of Gotland with localities mentioned in the text (after Hoel 2007, modified).

All specimens described in this paper are deposited in the Swedish Museum of Natural History, Stockholm (acronym NRM-PZ).

Abbreviations: $\mathrm{L}$ - length, $\mathrm{W}$ - width, $\mathrm{H}$ - height, sn. - parish (in Swedish).

\section{Systematic palaeontology}

Order Lingulida Waagen, 1885

Superfamily Discinoidea Gray, 1840

Family Trematidae Schuchert, 1893

\section{Genus Schizocrania Hall \& Whitfield, 1875}

Type species. - ?Orbicula filosa Hall, 1847; Trenton Group, Ordovician; New York State, USA.
Schizocrania striata (J. de C. Sowerby, 1839)

Figure 3J-L

1839 Orbicula striata J. de C. Sowerby in Murchison, p. 610 , pl. 5 , fig. 12 .

1854 Orbicula striata J. de C. Sowerby. - Murchison, pl. 20, fig. 3.

1859 Discina striata (J. de C. Sowerby). - Murchison, pl. 20, fig. 3 .

1866 Discina striata Sow. (sp.). - Davidson, p. 67, pl. 6, figs $1-4$.

1867 Discina striata (J. de C. Sowerby). - Murchison, pl. 20, fig. 3 .

1872 Discina striata (J. de C. Sowerby). - Murchison, pl. 20, fig. 3 .

1902 Orbicula striata J. de C. Sowerby. - Blake, p. 6.

1963 Schizocrania striata (J. de C. Sowerby). - Holland et al., p. 154.

1978 Schizocrania striata (J. de C. Sowerby, 1839). Cocks, p. 26.

1980 Schizocrania striata (Sowerby). - Lockley \& Antia, text-fig. 2A-C.

2006 Schizocrania striata (J. de C. Sowerby, 1839). Mergl, p. 217, fig. 3A-I.

Material. - Dorsal valves: NRM-PZ Br 23945, NRM-PZ Br 23946, NRM-PZ Br 23993, NRM-PZ Br 23994, NRM-PZ Br 24016, NRM-PZ Br 24497, NRM-PZ Br 62737.

Description. - See Mergl (2006).

Remarks. - There are no substantial morphological differences between the specimens from Great Britain and Gotland except for the prominence of concentric ornament on the dorsal valve. On the shells from Gotland, the concentric lines in the midsector are very prominent and attain a similar size as the radial costellae in some large dorsal valves (Fig. 3L). The intersections of concentric and radial fila form an irregularly reticulate, pitted ornament somewhat similar to that found in the Ordovician genera Drabodiscina Havlíček, 1972 and Tethyrete Havlíček, 1994. This reticulate ornament is highly variable on the same shell as well as in different individuals and does not justify separation of the Gotland specimens as a new species.

As well as in the British specimens, the Gotland specimens of Schizocrania striata (J. de C. Sowerby, 1839) differs from the Gotland specimens of Schizocrania verneuilii (Davidson, 1848) in possessing a finer radial ornament on the dorsal valve, with almost equally wide costellae and interspaces. In contrast, interspaces on the dorsal valve of $S$. verneuilii are broader than the costellae.

Occurrence of Gotland specimens of S. striata stratigraphically precedes the range of species in Britain. The 


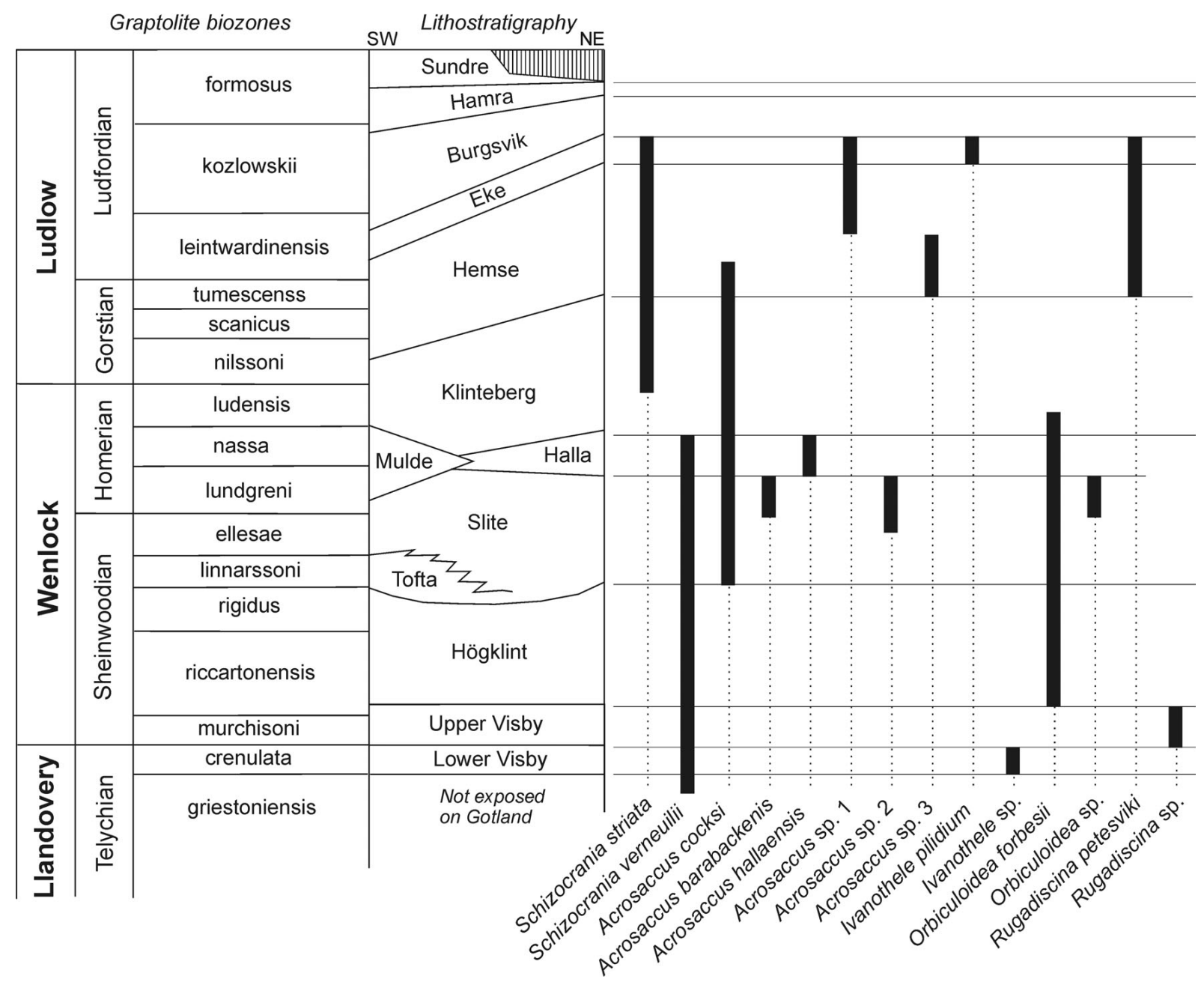

Figure 2. Stratigraphical ranges of revised Gotland discinoid brachiopods (after Hoel 2007, modified).

early occurrence in Gotland is in the late Homerian Klinteberg Formation and ranges to the late Gorstian Eke Formation, unlike the Gorstian to Ludfordian range of the British specimens.

Distribution. - Wenlock or Ludlow, Klinteberg Formation, railway cutting north to Däpps (Fröjel sn.), Fröjel (Fröjel sn.); Ludlow, Gorstian, Hemse Beds, upper part, Sandarve Kulle (Sandarve 2); Eke Formation, Lau Backar (Lau sn.).

\section{Schizocrania verneuilii (Davidson, 1848)}

Figure 3A-I

1848 Orbicula Verneuilii Davidson, p. 334, pl. 3, fig. 47. 1866 Discina Verneuilii Dav. - Davidson, p. 68, pl. 6, fig. 5. 1978 Schizocrania verneuilii (Davidson, 1848). - Cocks, p. 26.

2006 Schizocrania verneuilii (Davidson, 1848). - Mergl, p. 218 , fig. $3 \mathrm{~J}-\mathrm{P}$.
Material. - Specimens: NRM-PZ Br 23941, NRM-PZ Br 23942, NRM-PZ Br 23943, NRM-PZ Br 24013, NRM-PZ Br 24027, NRM-PZ Br 24333, NRM-PZ Br 24494, NRM-PZ Br 24495, NRM-PZ Br 24496.

\section{Description. - See Mergl (2006).}

Remarks. - The species Orbicula verneuilii was originally described by Davidson (1848) from the Homerian Much Wenlock Limestone Formation of Great Britain. It is characterized by large shell size with comparatively thin shell (ca $0.1 \mathrm{~mm}$ anteromedianly), an almost circular outline with blunt dorsal apex, and remarkably broad interspaces between fine costellae on the dorsal valve. The Gotland specimens are less deformed than the British ones and several specimens are preserved in a bivalved configuration with the ventral valve preserved inside the dorsal valve (Fig. 2C). Morphology of the ventral valve with a ventrally inflexed periphery of otherwise planar valve (specimen NRM-PZ Br 24495; Fig. 3H) indicates that between the 
ventral valve and substrate, a 2 to $3 \mathrm{~mm}$ high slit have remained in large individuals during life.The pedicle holds the posterior part of the shell some distance above the substrate while the anterior and anterolateral ventrally curved periphery of the ventral valve was almost touching the substrate. Abandoned cephalopod shells, stromatoporoids and corals have been observed among substrates utilized by specimens from Gotland. This indicates that the species preferred any available hard and effectively stable substrate for fixation.

Specimens confidently referred to $S$. verneuilii come from the Slite and Mulde formations. One smaller specimen (NRM-PZ Br 24013) which may also belong to the same species comes from the (?Lower) Visby Formation.

Distribution. - Gotland, Llandovery or lower Wenlock, (?Lower) Visby Formation, Visby (Norderstrand); Wenlock, Sheinwoodian, Slite Formation, Storvede (Follingbo sn.), Atlingbo canal (Atlingbo sn.); Mulde Formation, Djupvik (Eksta sn.).

Family Discinidae Gray, 1840

\section{Genus Acrosaccus Willard, 1928}

Type species. - Acrosaccus shuleri Willard, 1928; Caradoc, Ordovician; Virginia, U.S.A.

\section{Acrosaccus cocksi Mergl, 2006}

Figure 6E, H-M

?1866 Discina rugata Sow. (sp.). - Davidson, p. 63, pl. 5, fig. 18.

1965 Orbiculoidea forbesi (Davidson). - Rowell, p. H 285, fig. 178, 7.

2000 Orbiculoidea? forbesii (Davidson). - Holmer \& Popov, p. 90, figs $43,2 \mathrm{a}-\mathrm{c}$.

2006 Acrosaccus cocksi Mergl, 2006. - Mergl, p. 220, fig. 4A-P.

Material. - Four complete shells and four (dorsal and ventral) valves: NRM-PZ Br 23918, NRM-PZ Br 23919, NRM-PZ Br 23927, NRM-PZ Br 23929, NRM-PZ Br 23931, NRM-PZ Br 23933, NRM-PZ Br 24487, NRM-PZ Br 24488.
Description. - The shell is equally biconvex, rectimarginate, $11 \mathrm{~mm}$ wide in large specimens, having remarkably thick wall relative to shell size. The outline is subcircular, with evenly curved margins. L/W ranges near 1.0. The maximum width is at the mid-length. The dorsal valve is conical, $c a$ $25 \%$ as high as wide, with a low apex situated slightly posterior to the mid-length. The posterior slope is straight in axial profile. The anterior and lateral slopes are weakly convex.

The ventral valve is asymmetrically conical, $35-40 \%$ as high as wide, with a prominent apex situated between the posterior third and mid-length of the valve, having the top directed anteroventrally. The posterior slope is moderately sloping. The anterior slope and flanks are slightly convex. The pedicle track is spindle-shaped, slightly tapering anteriorly, occupying about half of the posterior slope. The bottom of the track is deep, closed by a distinct listrium with steep outer listrial plates.

The ornament consists of densely packed, and in some places somewhat irregular concentric rugellae, variable in a size, separated by deep narrower interspaces.

Remarks. - Gotland shells referred to Acrosaccus cocksi Mergl, 2006 are indistinguishable from the British specimens from the Coalbrookdale Formation (Wenlock) except for the more regular concentric rugellae. The Gotland specimens are derived from the Slite (Sheinwodian), Halla (Homerian), and Hemse formations (Gorstian). Lack of material and detailed stratigraphical data make it difficult to know whether this species has a long stratigraphical range or whether the available material comprises two closely related successive species.

Distribution. - Wenlock, Sheinwoodian, Slite Formation, Fårö (Fårö sn.); Homerian, Halla Formation, Hörsne canal (Hörnse sn.); Ludlow, Gorstian, Hemse Formation, Petesvik (Hablingbo sn.).

\section{Acrosaccus barabackensis sp. nov.} Figure 4A-L

Holotype. - Almost complete ventral valve, NRM-PZ Br 23907, figured herein on Fig. 4C, E, H.

Paratype. - Incomplete dorsal valve, NRM-PZ Br 23908, figured herein on Fig. 4J, K.

Figure 3. A-I - Schizocrania verneuilii (Davidson, 1848). Wenlock, Sheinwoodian, Mulde Formation, locality Djupvik (A, C, D, G-I); Llandovery or lower Wenlock, (?Lower) Visby Formation, locality Visby, Norderstrand (B, E, F). • A - small shell attached to cephalopod shell, NMR-PZ Br 24027. $\bullet$ B, E, F- dorsal valve, oblique view, and detail of ornament near anterior margin, NMR-PZ Br 24013. • C, D, I - complete shell attached to cephalopod shell, dorsal valve, oblique view, and detail of reticulate ornament near shell midlength, NMR-Br24494. • G, H - ventral valve and its counterpart, NMR-PZ Br 24495. J-L - Schizocrania striata (J. de C. Sowerby, 1839). Wenlock or Ludlow, Klinteberg Formation, locality Däpps, railway cutting (J); Ludlow, Gorstian, Hemse Beds, upper part, Sandarve (K, L). $\mathrm{J}$ - dorsal valve, NMR-PZ Br 62737. $\bullet \mathrm{K}, \mathrm{L}-$ dorsal valve and detail of reticulate ornament, NMR-PZ Br 24016. Bar = $2 \mathrm{~mm}$. 
Michal Mergl • A review of Silurian discinoid brachiopods from Gotland

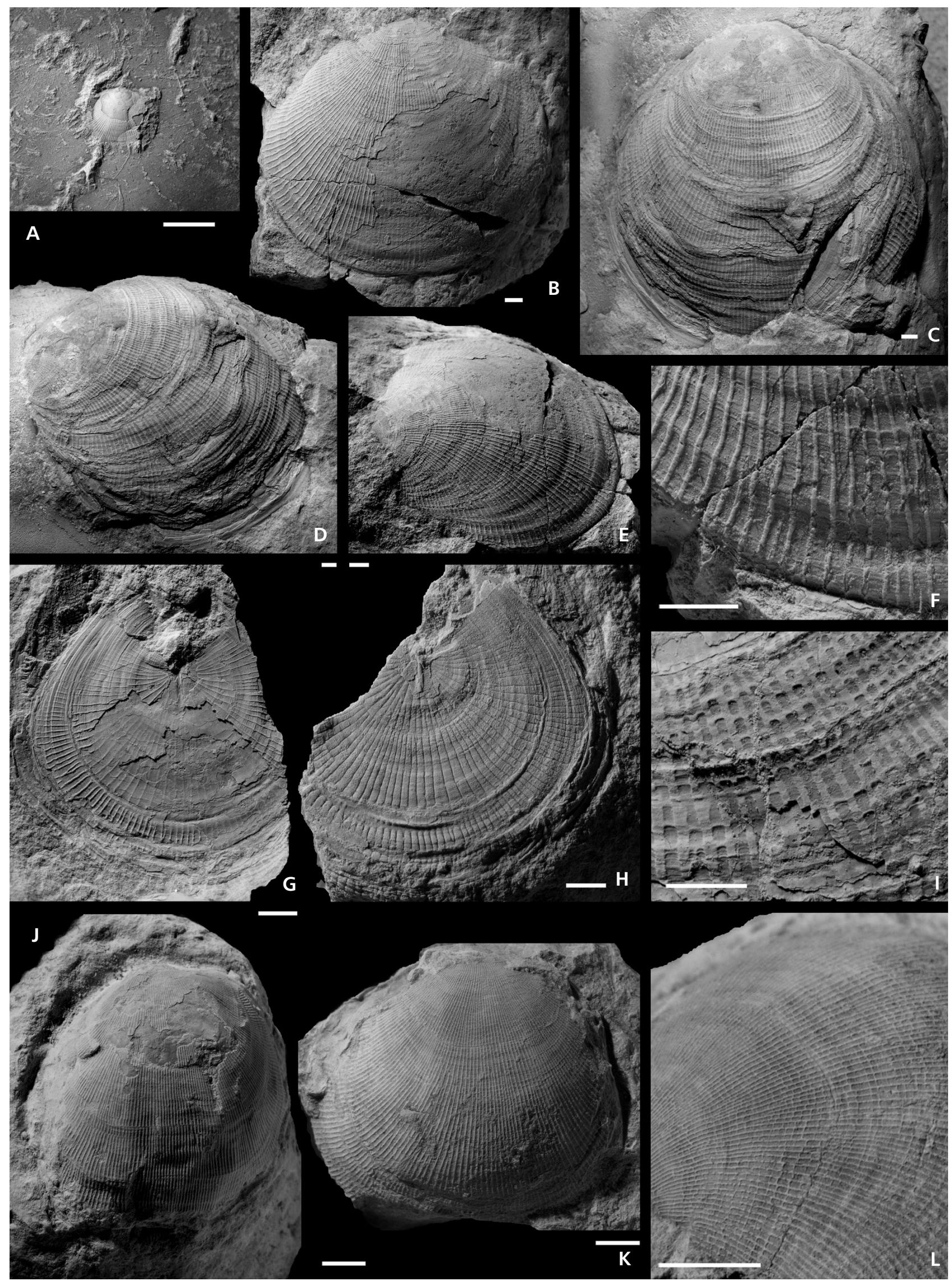


Type horizon. - Wenlock, Homerian, Slite Formation.

Type locality. - Gotland, Hörnse sn., Bara backe.

Etymology. - Bara backe, name of the Gotland site.

Material. - Twenty-six valves (dorsal and ventral): NRM-PZ Br 23887 to NRM-PZ Br 23898, NRM-PZ Br 23900 to NRM-PZ Br 23911, NRM-PZ Br 24022, NRM-PZ Br 24023.

Diagnosis. - Subequally biconvex, moderately sized Acrosaccus with broadly oval to elongately trapezoidal outline, weakly convex dorsal valve, and submarginal dorsal apex; ornamentation of fine growth lines on dorsal valve and thin, fine low rope-like rugellae on the ventral valve; dorsal visceral area small, weakly impressed, with fine median ridge in umbonal part.

Description. - The shell is biconvex, broadly oval to broadly trapezoidal in outline, with moderately thick shell, thickened along the pedicle track, $14-15 \mathrm{~mm}$ long.

The dorsal valve is broadly oval to subtrapezoidal, somewhat tapering in posterior half. The maximum width is anterior to midlength. $\mathrm{L} / \mathrm{W}=1.00$ to 1.20 . The apex is submarginal, situated in posterior $15-10 \%$ of length, facing posterodorsally to almost posteriorly depending on shell size. Shell margins are well rounded except for axial posterior which is almost straight. The valve is weakly convex transversally, with steep, concave posterior slope and gently convex anterior slope. Interior is devoid of a distinctly defined visceral field, only a thin long median ridge extends from the apical chamber to midlength.

The ventral valve is low bell-shaped, with apex at about $40 \%$ of the shell length. The apex faces anteroventrally. The posterior slope is straight or having a gently convexo-concave axial profile. The anterior slope is also convexo-concave in profile, with flattened anterior part. The pedicle track is prominent, narrowly spindle-shaped, occupying most of the posterior slope leaving only short mineralised shell near the posterior margin. Outer listrial plates are well developed, narrow, and bearing district forward curved growth lines. The plates are steeply sloping toward the bottom of the track from adjacent shell surface bordered by an acute edge. Inner listrial plates are narrow having a distinct suture in between. Posterior termination of the pedicle track is narrowly acute. External pedicle opening is small, opened internally by similarly sized foramen. A distinct pedicle tube is absent. The ventral visceral field is not discernible. Scars of anterior adductors are weakly impressed anterolaterally to the apex. Inner surface bears radially disposed distal canals of the vascular system.

Exterior of the dorsal valve bears fine, low growth lines of uneven size, more prominent on posterolateral flanks. The ventral valve bears weak growth lines, which are intercalated between fairly distant $(0.5-0.6 \mathrm{~mm}$ apart), raised fine concentric fila or rope-like rugellae.

Remarks. - The new species belongs to a group of discinids with long and prominent posteriorly closed pedicle track without continuation into an internal pedicle tube, and a low dorsal valve with a submarginal apex. The type species of the genus, the late Ordovician Acrosaccus shuleri Willard, 1928 also belongs to this group, representing a typical morphology of the genus. The new species differs from the few species that could be referred to the genus, e.g. Acrosaccus karlstejnensis (Mergl, 1996) and A. bohemicus (Barrande, 1879) by its longer pedicle track and weaker external ornamentation consisting of fine concentric lines and thin rugellae.

Distribution. - Wenlock, Homerian, Slite Formation, Bara backe (Hörnse sn.).

\section{Acrosaccus hallaensis sp. nov.}

Figures $4 \mathrm{M}-\mathrm{T}, 5 \mathrm{~A}-\mathrm{L}$

Holotype. - Incomplete ventral valve, NRM-PZ Br 108097 , figured herein on Fig. 4O, R.

Paratype. - Complete dorsal valve, NRM-PZ Br 108096, figured herein on Fig. 5A, B, D, F.

Type horizon. - Wenlock, Homerian, Halla Formation.

Type locality. - Gotland, Hörnse sn., Hörnse canal.

Etymology. - Halla, name of the Gotland site.

Figure 4. A-L-Acrosaccus barabackensis sp. nov. Wenlock, Homerian, Slite Formation, locality Bara backe (Hörnse sn.) • A - exfoliated ventral valve, NMR-PZ Br 23902. • B - partly exfoliated ventral valve, NMR-PZ Br 23869. C , E, H - holotype, ventral valve, oblique view, and detail of pedicle track. NMR-PZ Br 23907. $\bullet \mathrm{D}, \mathrm{F}, \mathrm{G}-$ incomplete ventral valve, oblique view, and detail of pedicle track, NMR-PZ Br 23893. $\bullet$ I - internal mould of dorsal valve, NMR-PZ Br 24022. • J, K - paratype, incomplete dorsal valve and its oblique view, NMR-PZ Br 23908. $\bullet$ L - dorsal valve, NMR-PZ Br 23891. • M-T - Acrosaccus hallaensis sp. nov. Wenlock, Homerian, Halla Formation, locality Hörsne canal. $\bullet \mathrm{M}, \mathrm{N}, \mathrm{P}, \mathrm{Q}-$ small ventral valve in posterior, ventral, and oblique views, and detail of pedicle track, NMR-PZ Br 108117. • O, R - holotype, partly exfoliated ventral valve, and detail of pedicle track, NMR-PZ Br 108097. - $\mathrm{S}$ - internal mould of ventral valve, NMR-PZ Br 108098. $\bullet$ T apical part of ventral valve, NMR-PZ Br 108105. Bar $=2$ mm if not otherwise stated. 
Michal Mergl • A review of Silurian discinoid brachiopods from Gotland

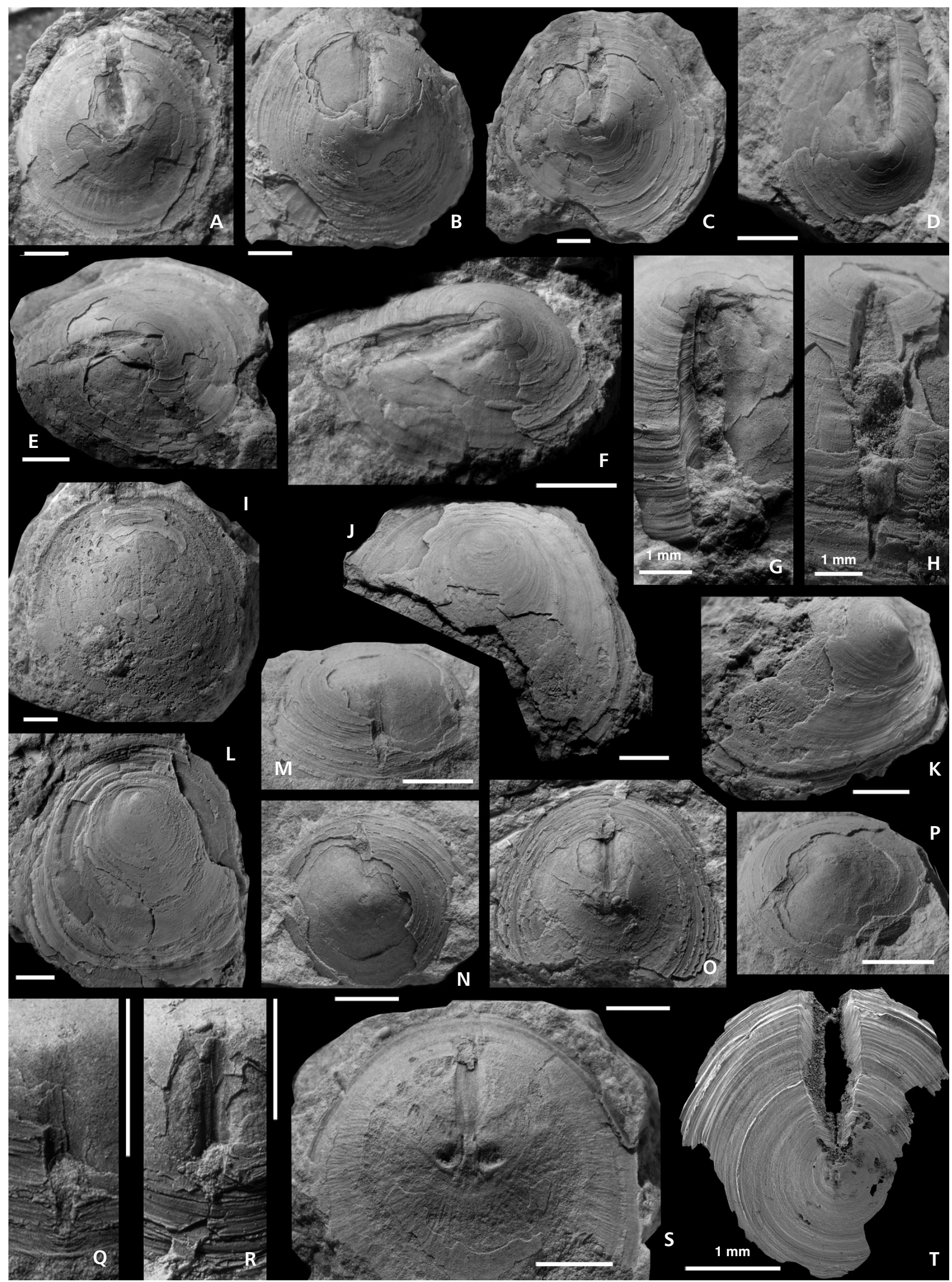


Material. - Twenty-two valves (dorsal and ventral): NRM-PZ Br 108096 to NRM-PZ Br 108117.

Diagnosis. - Subequally biconvex, moderately sized Acrosaccus with subcircular to broadly trapezoidal outline, weakly convex dorsal valve, and submarginal dorsal apex; ornamentation of fine, somewhat wrinkled growth lines on dorsal valve and thin lamellose rugellae developed in the later growth stages of the ventral valve; dorsal visceral area small, weakly impressed, with fine median ridge in umbonal part.

Description. - The shell is biconvex, subcircular to broadly trapezoidal in outline, thin-walled, gently thickened along the pedicle track, $14-15 \mathrm{~mm}$ long.

The dorsal valve is broadly oval to subtrapezoidal, somewhat tapering in posterior half. Maximum width is anterior to midlength. $\mathrm{L} / \mathrm{W}$ is approximately 1.00 , with tendency towards having a broader outline with shell size. The apex is submarginal, situated in $7-10 \%$ of length, facing posterodorsally to almost posteriorly. Shell margins are well rounded except for axial posterior, which is less curved. The valve is weakly convex transversally, with steep, concave posterior slope and weakly convex anterior slope. The visceral field is weakly defined, with small scars of oblique anterior adductors separated by a thin median ridge. The internal surface bears fine radial distal canals of the vascular system.

The ventral valve is low conical to bell-shaped, with apex at about $40 \%$ of the shell length. The apex is faced anteroventrally. The posterior slope is straight to gently convexo-concave in an axial profile. The anterior slope is also convexo-concave in profile, with flattened anterior part. The pedicle track is prominent, narrowly spindle-shaped, occupying most of the posterior slope leaving only short mineralised shell near the posterior margin. Outer listrial plates are narrow, well developed having district forwardly curved growth lines. They are steeply sloping toward the bottom of the track, from adjacent shell surface bordered by acute edge. Internal listrial plates are planar, narrow, having a distinct suture in between. Posterior termination of the pedicle track is narrowly acute. External pedicle opening is small, opened internally by similarly sized foramen. A pedicle tube is absent. The ventral visceral field is weakly defined. Scars of anterior adductors are finely impressed anterolaterally to the apex. Scars of other muscles are also visible but with blurred outlines. Inner surface bears radially disposed distal canals of the vascular system.

Exterior of the dorsal valve bears fine, low growth lines of uneven size interrupted at irregular intervals by coarser growth lines of fila. The ventral valve bears weak growth lines with numerous, fine, lamellose growth rugellae. These fine rugellae have swollen rope-like crests and are more densely crowded along shell periphery of large shells.
Microornament of the post-larval shell consists of radial rays consisting of sets of broadly oval pits on $3 \mu \mathrm{m}$ wide (Fig. 5K, L). Rays are superimposed on the nearly smooth surface. Width of rays varies significantly depending on numbers of pits. Some rays are terminated at distinct growth lines, but it is obvious, that this termination is an effect of non-imprinting of vesicles into mineralised primary shell layer (Fig. 5L). Fine pitting is terminated by acute edge of the primary shell just near margins of the pedicle track (Fig. 5J). There, the primary shell layer with pitting is absent and the secondary shell layer of the outer listrial plates is preserved.

Remarks. - The new species is very similar to Acrosaccus barabackensis sp. nov., which is also of comparable age. The main differences concern the thickness of the shell and ornament. The shell of A. hallaensis is thinner but, its ornamentation is coarser, with higher and more numerous lamellose rugellae on the ventral valve. Outlines of both species are similar, although posterior margin is a more rounded in the dorsal valve of $A$. hallaensis and the dorsal apex of this species is more posterior compared with that of A. barabackensis sp. nov. Regardless, the concentric ornament in A. hallaensis is finer compared with those in A. karlstejnensis (Mergl, 1996), A. bohemicus (Barrande, 1879) and A. shuleri Willard, 1928.

Distribution. - Wenlock, Homerian, Halla Formation, Hörsne canal (Hörnse sn.).

\section{Acrosaccus sp. 1}

Figure 6A-D, F, G

Material. - Five dorsal valves and their counterparts, and two incomplete dorsal valves: NRM-PZ $\mathrm{Br} 23922$, NRM-PZ Br 23923, NRM-PZ Br 24025, NRM-PZ Br 24026, NRM-PZ Br 24196 to NRM-PZ Br 24198, NRM-PZ Br 24199 to NRM-PZ Br 24201, NRM-PZ Br 24477.

Description. - All available dorsal valves are planar, with gently convex small apical region, with width about 7 to $10 \mathrm{~mm}$. The outline is subcircular having L/W less than 1, with distinct irregularity in some shells. The larval shell is $300 \mu \mathrm{m}$ long, subcircular, moderate convex. The initial post-larval shell is nearly smooth, the first rugella appears at about $3 \mathrm{~mm}$ long shell. Ornamentation consists of high, lamellose and thickly packed concentric rugellae of uniform size. There are 8 rugellae per $2 \mathrm{~mm}$ anteromedianly.

Remarks. - The shell differs from A. cocksi Mergl, 2006 by having a planar valve and more densely packed rugellae, with narrower interspaces. In general morphology the dorsal valves are similar to dorsal valves of Emsian and 


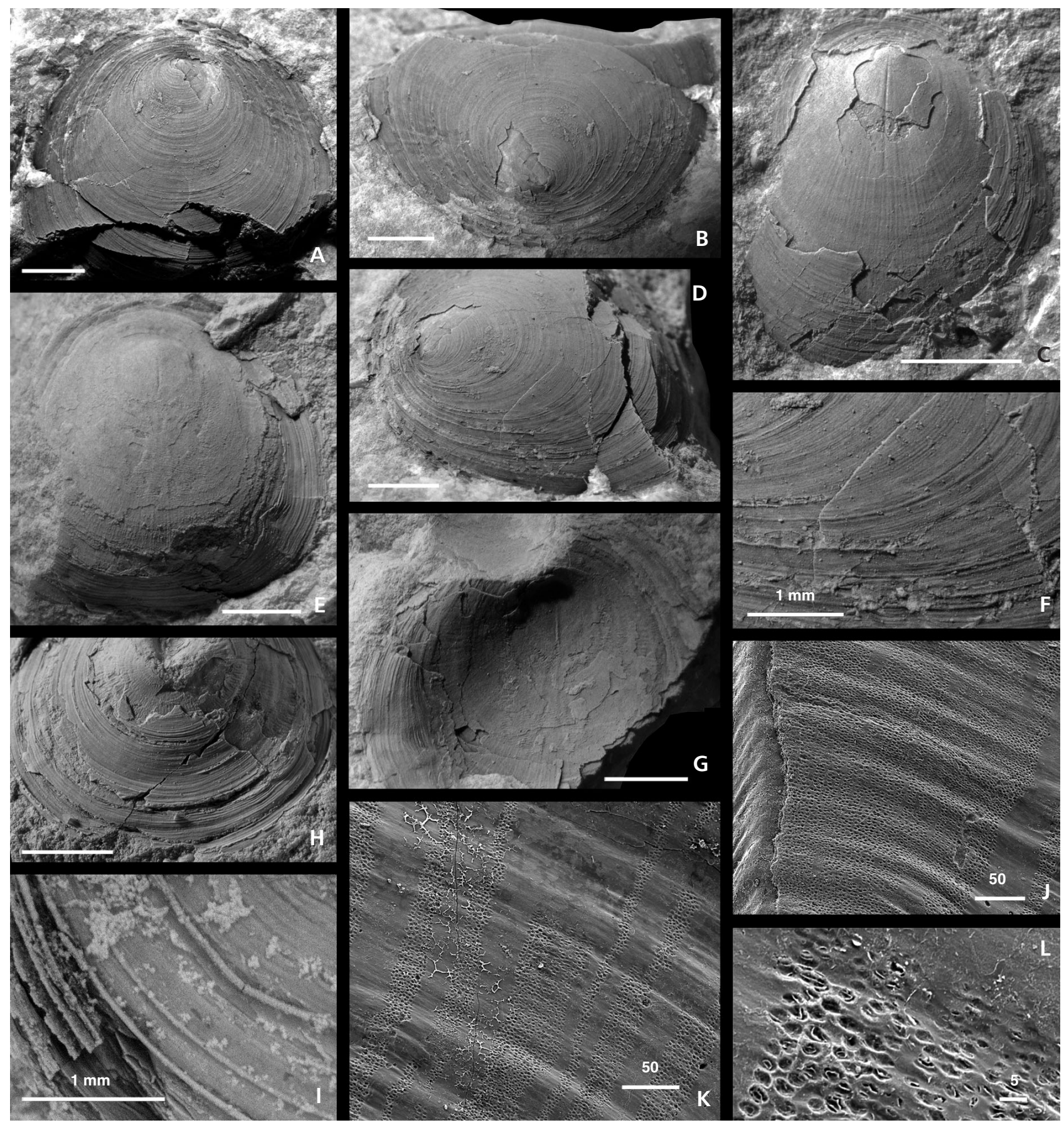

Figure 5. Acrosaccus hallaensis sp. nov. Wenlock, Homerian, Halla Formation, locality Hörsne canal. • A, B, D, F - paratype, dorsal valve in dorsal, posterodorsal, and oblique views, and detail of ornament, NMR-PZ Br 108096. $\bullet$ C - exfoliated dorsal valve, NMR-PZ Br 108104. $\bullet$, G - dorsal valve, internal mould and interior, NMR-PZ Br 108115. $\bullet \mathrm{H}$ - ventral valve showing ornamentation, NMR-PZ Br 108101 • I-L - ventral valve, detail of ornament (I), microornament near pedicle track (J), in posterolateral shell (K) and detail of pitting $(\mathrm{L}), \mathrm{NMR}-\mathrm{PZ} \mathrm{Br} 108105$. Bar $=2 \mathrm{~mm}$ if not otherwise stated (in $\mu \mathrm{m})$.

Eifelian age of the Barrandian, referred by Mergl (2008) and Mergl \& Ferrová (2009) to Acrosaccus Willard, 1928.

Distribution. - Ludlow, Gorstian, Hemse Formation, Duckarve (Linde sn.); Ludlow, Ludfordian, Eke Formation, Lau backar (Lau sn.).

\section{Acrosaccus sp. 2}

Figure $8 \mathrm{~N}, \mathrm{O}$

Material. - One ventral valve: NRM-PZ Br 23949.

Remarks. - The ventral valve shows remarkably coarse 
concentric rugellae and $\mathrm{V}$-shaped pedicle track with narrow outer listrial plates. This valve cannot be definitely referred to other species of the genus known from Gotland.

Distribution. - Wenlock, Sheinwoodian, Slite Formation, Follingbo (Follingbo sn.).

\section{Acrosaccus sp. 3}

Figure 8P, Q

Remarks. - In the collections, there are numerous specimens coming from marls of the Hemse Formation that cannot be referred to any other described species of the genus. The material is not well enough preserved for formal description; two specimens for comparative purpose are figured here (Fig. 8P, Q).

Distribution. - Ludlow, Gorstian, Hemse Formation, Lau Kanal (Lau sn).

\section{Genus Ivanothele Mergl, 1996}

Type species. - Ivanothele mordor Mergl, 1996; Ludlow, Gorstian, Kopanina Formation; Barrandian, Bohemia.

\section{Ivanothele pilidium (Lindström, 1861)}

Figures 7, 8C, F-J

1861 Discina pilidium n. sp. Lindström, p. 375, pl. 13, fig. 20.

Material. - One juvenile and one large incomplete ventral valves: NRM-PZ Br 23964, NRM-PZ Br 23995.

Description. - The large ventral valve is $8 \mathrm{~mm}$ high; its length and width are unknown. Anterior slope is steep, concavo-convex in axial profile, posterior slope unknown. Lateral slopes steeply sloping, with step-like aspect. The apex is pointed, slightly curved anteroventrally.

The pedicle track is very small (in estimation less than
$10 \%$ of the posterior slope), very broad respective to its length, with planar outer listrial plates and thin, linear inner plate. The listrium faces posteroventrally.

Ornament consists of prominent, raised strong concentric rugellae with broad bases, 5 to 6 per $2 \mathrm{~mm}$ anteromedianly. Interspaces are wide as rugellae, deeply concave in profile. Irregularities in the course of rugellae are quite common.

Dorsal valve is unknown, but after the illustration of Lindström (1861) it should be planar or weakly concave.

Remarks. - This peculiar species was originally described by Lindström (1861) but the original species is not amongst type specimens of Lindström's work stored in the Swedish Museum of Natural History in Stockholm. Two specimens are now available in these collections, but one of them, the ventral valve of a young specimen is restricted in stratigraphical data. The original Lindström collections came from Lauberg (= Lau backar), indicating a Ludlow age (probably Eke Formation). His original drawing is re-figured here (Fig. 7).

A distinct highly conical shape, planar dorsal valve, tiny pedicle track, and coarse rugellate ornamentation of the valve indicate assignment of Discina pilidium Lindström, 1861 to the genus Ivanothele Mergl, 1996. The only known species of the genus, Ivanothele mordor Mergl, 1996 from the Kopanina Formation (Gorstian, Ludlow) differs from Ivanothele pilidium by a lower conical ventral valve and probably larger pedicle track. However, there is remarkable shell variability with suppression of bilateral symmetry in $I$. mordor. At present, a deficiency of specimens from Gotland makes reliable comparison impossible, but new material of the Gotland species may eventually prove that I. mordor is a younger synonym of I. pilidium.

Distribution. - Ludlow, Ludfordian, Eke Formation, Lau backar (Lau sn.); probably also Wenlock (Sheinwoodian) strata in surroundings of Visby.

\section{Ivanothele sp.}

Figure 8A, B, D, E

Material. - One complete shell: NRM-PZ Br 24203.

\footnotetext{
Figure 6. A-D, F, G-Acrosaccus sp. 1. Ludlow, Gorstian, Hemse Formation, Duckarve (A-D, F); Ludlow, Gorstian, Eke Formation, Lau backar (G). - A - dorsal valve, NMR-PZ Br 24199. • B, C - dorsal valve, oblique view, NMR-PZ Br 24025. • D - incomplete dorsal valve, NMR-PZ Br 24200. - F - dorsal valve, NMR-PZ Br 24201. • G - external mould of dorsal valve, NMR-PZ Br 24477. • E, H-M - Acrosaccus cocksi Mergl, 2008. Wenlock, Sheinwoodian, Slite Formation, locality Fårö (I, J, L, M), Homerian, Halla Formation, locality Hörsne canal (H); Ludlow, Gorstian, Hemse Formation, locality Petesvik (E, K). • E - dorsal valve interior, NMR-PZ Br 23931. $\bullet \mathrm{H}$ - deformed ventral valve, NMR-PZ Br 108095. • I, L - complete shell, dorsal and ventral valves, NMR-PZ Br 24487. • J, M - complete shell, dorsal valve and lateral view, NMR-PZ Br 24488. $\bullet$ K - complete shell, ventral valve, NMR-PZ Br 23927. • N-U - Orbiculoidea forbesii (Davidson, 1848). Wenlock Series, Sheinwoodian, Högklint Formation, locality Visby, Kirkbeyet (Q); Slite Formation, localities Fårö (N-P, R, S), Skäret (T, U). • N-P, R, S - complete shell, lateral view, oblique view, ventral valve, detail of pedicle track, and dorsal valve, NMR-PZ Br 24486. • Q - dorsal valve, NMR-PZ Br 131740. • T, U - dorsal valve, detail of ornament, NMR-PZ Br 23877. Bar = $2 \mathrm{~mm}$ if not otherwise stated.
} 
Michal Mergl • A review of Silurian discinoid brachiopods from Gotland

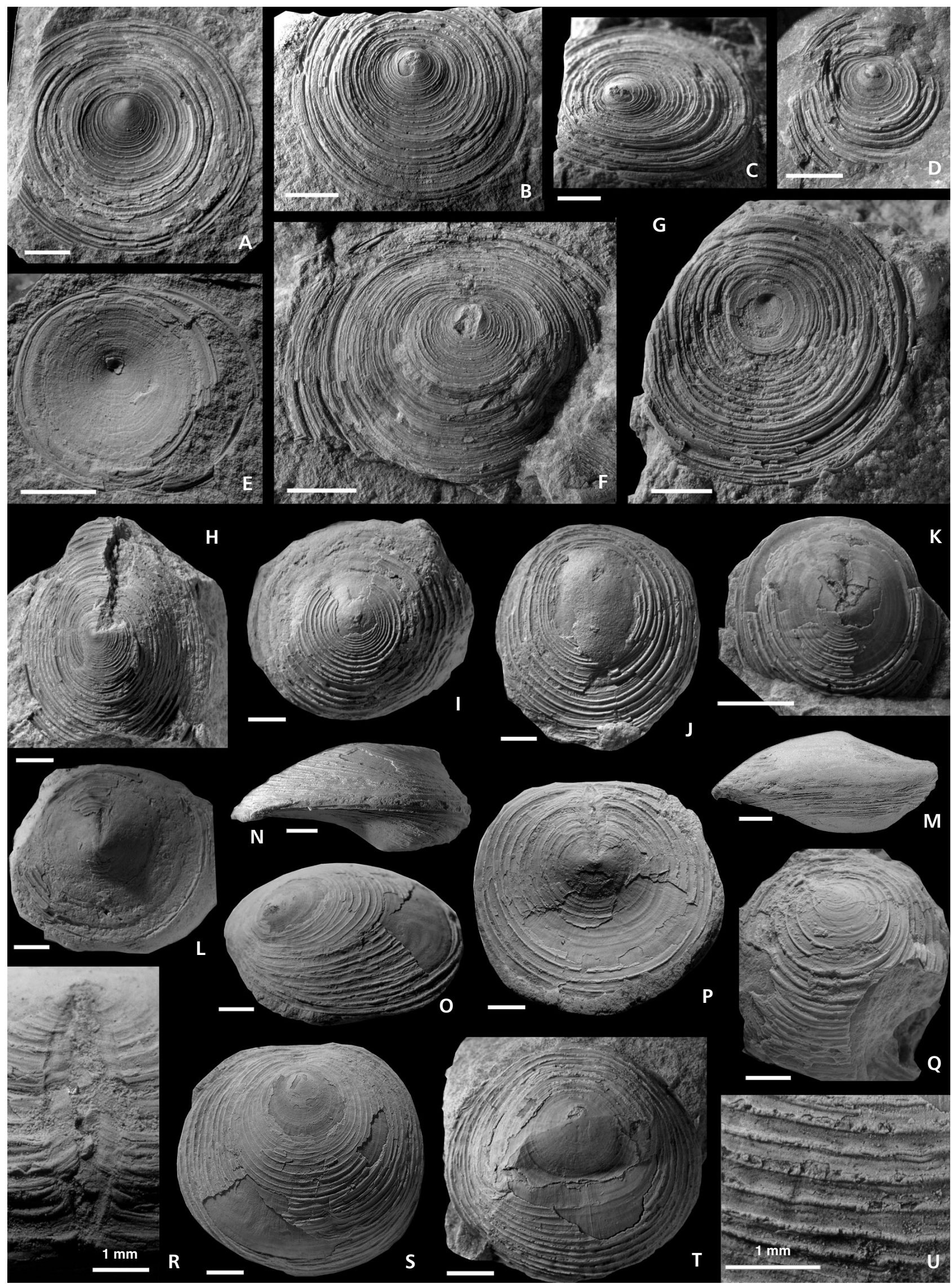




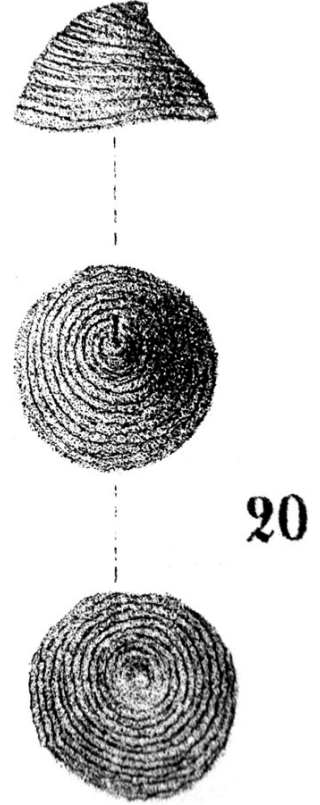

Figure 7. Ivanothele pilidium (Lindström, 1861). Original drawing of Lindström (1861), a complete specimen from Lauberg, probably from the Eke Formation.

Description. - The shell is thick-shelled having moderately convex dorsal valve and asymmetrically conical ventral valve. Shell length is $8.5 \mathrm{~mm}, \mathrm{~L} / \mathrm{W}=1.2, \mathrm{~L} / \mathrm{H}=0.15$. Dorsal valve has submarginal apex, situated at $17 \%$ of shell length, and is evenly convex in transverse and axial profiles.

The ventral valve has apex situated at $37 \%$ of shell length. The valve has gently convex posterior slope and concave anterior slope. Pedicle track is $1.8 \mathrm{~mm}$ long and $1 \mathrm{~mm}$ wide facing posteroventrally. Outer listrial plates are almost planar, large, leaving only a narrow strip in between. Inner listrial plates are unknown. Interiors of both valves are unknown.

Ornamentation consists of low concentric rugellae having broad bases separated by flat interspaces of comparable size. Interspaces bear up to five fine concentric growth lines. There are 5 rugellae per $2 \mathrm{~mm}$ anteromedianly.

Remarks. - The shell shows a remarkable pedicle track which is broad, short and closed by planar and broad outer listrial plates. Its shape is similar to the track developed in Ivanothele Mergl, 1996 and Chynithele Havlíček, 1996. It is one of the oldest known discinids with this morphology of the pedicle track.

Distribution. - Late Llandovery, Lower Visby Formation; Norderstrand.

\section{Genus Orbiculoidea d'Orbigny, 1847}

Type species. - Orbicula forbesii Davidson, 1848, Wenlock, Silurian; West Midlands, England.
Orbiculoidea forbesii (Davidson, 1848) Figure 6N-U

1848 Orbicula Forbesii Davidson; p. 334, pl. 3, fig. 45 (top, upper detail, first and third from right, not second from right).

1866 Orbiculoidea Forbesii Dav. 1848. - Davidson, p. 73, pl. 7, fig. 16.

1978 Orbiculoidea forbesii (Davidson, 1848). - Cocks, p. 27 (pars).

2006 Orbiculoidea forbesii (Davidson, 1848). - Mergl, p. 226 , fig. $6 \mathrm{~A}-\mathrm{O}$.

Material. - One complete shell, three dorsal valves and one ventral valve: NRM-PZ Br 23765, NRM-PZ Br 23877 , NRM-PZ Br 23878, NRM-PZ Br 24486, NRM-PZ Br 131740 .

Description. - The shell is dorsibiconvex, rectimarginate, $12 \mathrm{~mm}$ long, rather thin-shelled relative to shell size. The outline is almost circular, with less rounded posterior margin. The one complete shell has $\mathrm{L} / \mathrm{W}=0.95$. The maximum width is at mid-length.

The dorsal valve is moderately convex transversally and axially, with the apex directed posterodorsally having $\mathrm{H} / \mathrm{W}=0.25$. The apex is located very posteriorly, separated from the posterior margin by a high, very steep, straight, slightly inflated posterior slope. Lateral slopes are gently convex. The dorsal valve interior is unknown.

The ventral valve is very low, asymmetrically conical, with the apex directed anteroventrally and located in the posterior $40 \%$ of the valve length. The posterior slope is weakly and evenly convex, anterior slope is concave in axial profile, flanks are almost planar. The pedicle track is narrowly spindle-shaped, occupying almost the whole length of the posterior slope. The track is acutely pointed in the posterior end. Outer listrial plates are slightly inclined, covered by prominent growth lines. Lines are clearly curved forward. Inner listrial plate is undivided, narrow. The ventral valve interior lacks a distinct visceral area; the vascular system is poorly impressed.

The ornament of the dorsal valve consists of distinct, almost uniformly sized concentric rugellae, rather regularly arranged on the post-larval shell, becoming less regular toward the margins. Rugellae are low, rounded, having stout bases, 8 in number per $5 \mathrm{~mm}$ some $7 \mathrm{~mm}$ from the apex. Rugellae on the ventral valve are similar, more distant, 5 to 8 per $2 \mathrm{~mm}$ anteromedianly. Microornament is unknown.

Remarks. - Despite moderate size of all individuals these can be referred to Orbiculoidea forbesii (Davidson, 1848). The British specimens differ by their larger size and higher dorsal valve, but the latter is surely related to the age of the specimen. The height, convexity, and ornamentation of the 


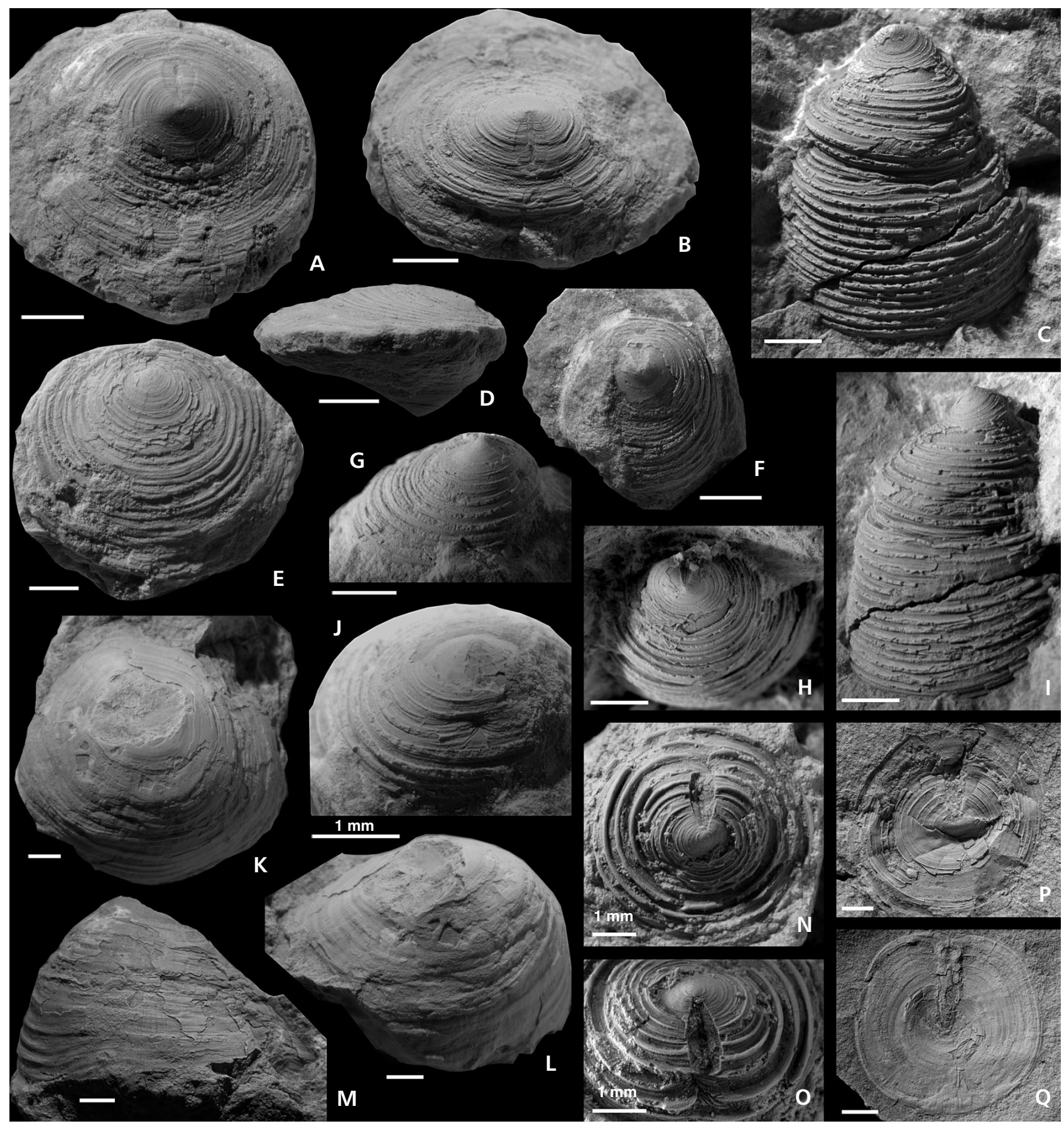

Figure 8. A, B, D, E - Ivanothele sp. Llandovery, Lower Visby Formation, locality Norderstrand. • A, B, D, E - complete shell, ventral valve, posteroventral view, lateral view, and dorsal valve, NMR-PZ Br 24203. • C, F-J - Ivanothele pilidium (Lindström, 1861). Wenlock, exact level unknown, locality Visby (F, G, J); Ludlow, Ludfordian, Eke Formation, locality Lau backar (C, H, I). • G, J - ventral valve, top view, oblique view and detail of pedicle track, NMR-PZ Br 23964. • C, H, I - incomplete ventral valve, oblique, ventral, and side views, NMR-PZ Br $23995-6 . \bullet N$, O - Acrosaccus sp. 2. Wenlock, Sheinwoodian, Slite Formation, Follingbo. $\bullet$ N, O - ventral valve in ventral and posteroventral views, NMR-PZ Br 23949 . $・$ P, Q - Acrosaccus sp. 3. Ludlow, Gorstian, Hemse Formation, locality Lau Kanal. • P - exterior of ventral valve, NMR-PZ Br 24143 . $-\mathrm{Q}-$ interior of ventral valve, NMR-PZ Br 24145. Bar = $2 \mathrm{~mm}$ if not otherwise stated.

Gotland specimens are comparable with the shape of the early growth stages of the British specimens. The length of the pedicle track is also related to shell size (see Mergl 2006, fig. 6A, B). The British specimens are known only from the
Much Wenlock Limestone of late Homerian age in a few historical British localities (Aldridge et al. 2000). The Gotland specimens are older being derived from the Högklint and Slite formations, respectively, which is roughly 
correlate to the lower part of the Coalbrookdale Formation in Britain. However, more precise stratigraphical and locality data are missing in all available Gotland specimens.

Lindström (1861, p. 375) reported Discina Forbesi Davidson, 1848 from Klinteberg and Djupvik localities, but without any illustrations and thus it is impossible to confirm his identification by modern standards.

Distribution. - Wenlock Series, Sheinwoodian, Högklint Formation; Visby, Kirkbeyet. Slite Formation, Fårö (Fårö sn.), Skäret (Fröjel sn.); Klinteberg Formation, Klinteberg.

\section{Orbiculoidea sp.}

Figure 8K-M

Material. - Two dorsal valves.

Description. - Both dorsal valves are medium sized, with largest specimen $15 \mathrm{~mm}$ wide, somewhat asymmetrically conical, with rounded apex, rather thin-walled relative to size. Posterior slope is very steep, anterior slope is straight or weakly concave. Despite fact that the apical region is worn in both specimens, courses of growth lines indicate that the apex of the shell was probably inclined anterodorsally. The shell ornament consists of low broad distant rugellae separated by almost bare interspaces.

Remarks. - These two specimens are remarkable for their large size and shell profile that is similar to the profile of some lower and middle Devonian giant discinids, exemplified by Orbiculoidea collis Clarke, 1913 (Boucot et al. 2001) and Gigadiscina lessardi (Mergl \& Massa 2005). The Gotland specimens are only one-fifth the size of these Devonian taxa, but the morphology is the same.

Distribution. - Wenlock, Homerian, Slite Formation, Bara backe (Hörnse sn.).

\section{Genus Rugadiscina Mergl, 2006}

Type species. - Orbicula rugata J. de C. Sowerby in Murchison, 1839; Ludfordian, Ludlow, Silurian; Ludlow, England.

\section{Rugadiscina petesviki sp. nov.} Figure 9A-O

Holotype. - Complete shell attached to a gastropod shell, NRM-PZ Br 23955a, figured on Fig. 9G, H, J (attached to latest gastropod shell whorl, right in Fig. 9N).

Type horizon. - Silurian, Ludlow, Gorstian, Hemse Beds.

Type locality. - Gotland, Hablingbo sn., Petesvik.

Etymology. - Petesvik, name of Gotland bay, the collecting site.

Material. - Eleven specimens: NMR-PZ Br 23924, NMR-PZ Br 23925, MR-PZ Br 23926, NMR-PZ Br23930, NMR-PZ Br23932, NMR-PZ Br 23934, NMR-Br 23935 , NMR-PZ Br 23955a-c. Two ventral valves attached to a bivalve: NMR-PZ Br 23948.

Diagnosis. - Rugadiscina with dorsal valve having fine growth fila, long pedicle track with prominent planar outer listrial plates.

Description. - The shell is convexoplane, rectimarginate, of moderate size, $10-14 \mathrm{~mm}$ wide in adult specimens, moderate thick-shelled relative to shell size. The outline is almost circular, with evenly curved margins. The length/width is weakly varying ( $\mathrm{L} / \mathrm{W}=0.86-1.05 ; \mathrm{n}=8$ ). The maximum width is at mid-length.

The dorsal valve is strongly convex, ca $30 \%$ as high as long, with maximum anterior to the apex. The apex lies in the posterior $15 \%$ of the valve length, and is directed posterodorsally to almost posteriorly. The posterior slope is short, weakly concave, steep. The anterior slope is evenly convex, the lateral slopes are nearly straight. The dorsal interior is weakly impressed. A remarkably small visceral area is restricted to the apical part and is divided by a short and weak median ridge.

The ventral valve is flat to resupinate in late adults, with subcentral, always slightly posteriorly situated apex. The apex is flat and rests on a weakly convex apical region. The pedicle track occupies about $80-85 \%$ of the length of post-apical shell. The track has a spindle-shaped outline,

Figure 9. A-N, O-Rugadiscina petesviki sp. nov. Ludlow, Gorstian, Hemse Formation, locality Petesvik (A-N); Ludlow, Ludfordian, Burgsvik Formation, locality Burgsvik (O). • A - external mould of ventral valve, NMR-PZ Br 23935. • B, D - external mould of ventral valve with partly preserved shell, dorsal and oblique views, NMR-PZ Br 23926. • C, F - external mould of ventral valve with partly preserved shell, dorsal and oblique views, NMR-PZ Br 23924. • E, M - external mould of ventral valve and detail of pedicle track, NMR-PZ Br 23930. • G, H, J - holotype, complete shell, dorsal valve with partly exposed ventral valve, dorsal, oblique and lateral views, NMR-PZ Br 23955a. • I - complete shell, exfoliated dorsal valve in oblique view, NMR-PZ Br 23955b. $\bullet \mathrm{K}, \mathrm{L}$ - collapsed dorsal valve, dorsal view, and detail of ornament, NMR-PZ Br 23932. $\bullet$ N - three complete specimens in life position attached to gastropod shell, NMR-PZ Br 23955. • O - ventral valve in life position attached to bivalve shell, NMR-PZ Br 23948. - P, Q - Rugadiscina sp. Wenlock, Sheinwoodian, Upper Visby Formation, locality Gnisvärd. • P, Q - external mould of ventral valve, NMR-PZ Br 23920. Bar $=2 \mathrm{~mm}$. 
Michal Mergl • A review of Silurian discinoid brachiopods from Gotland

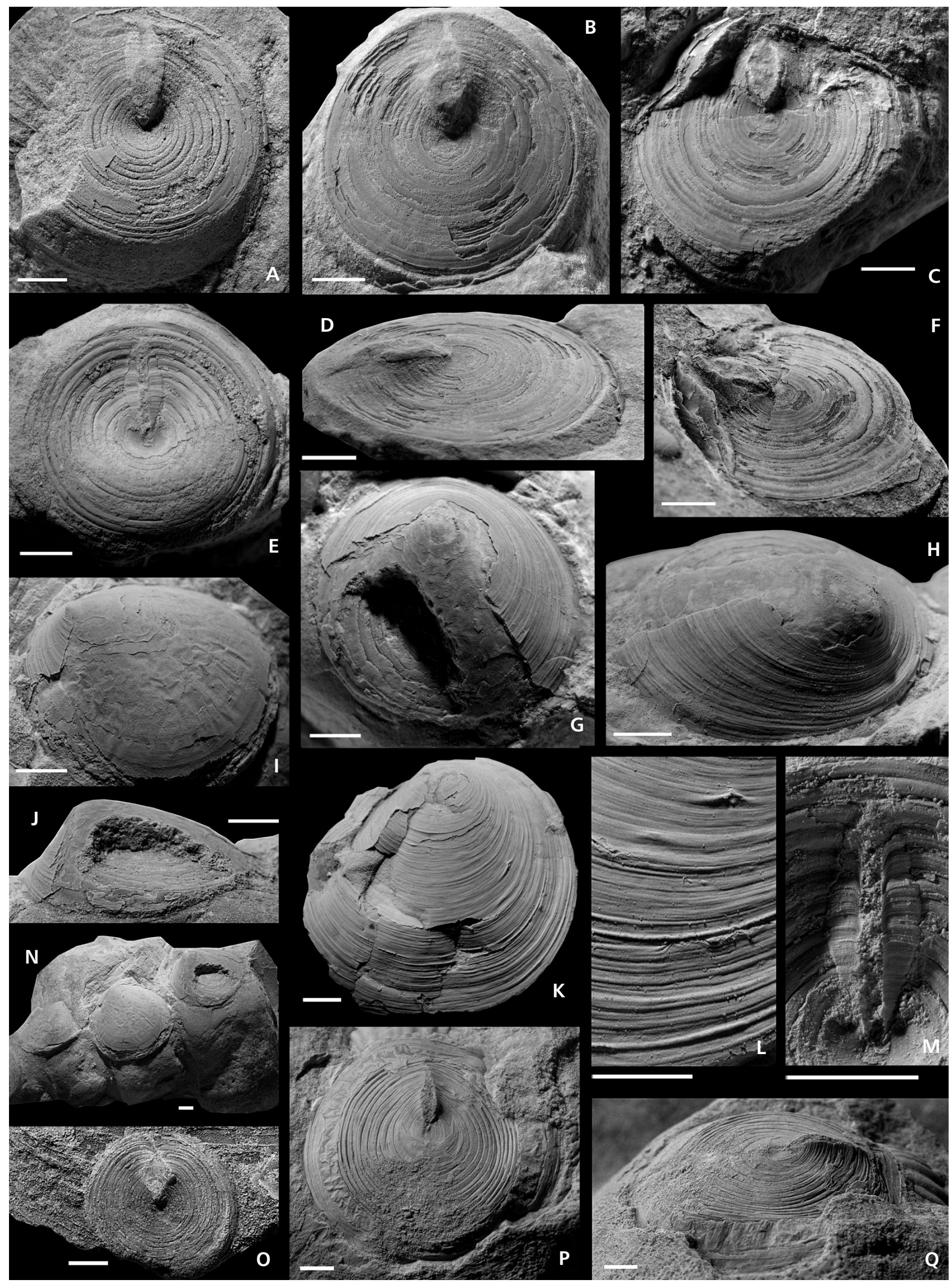




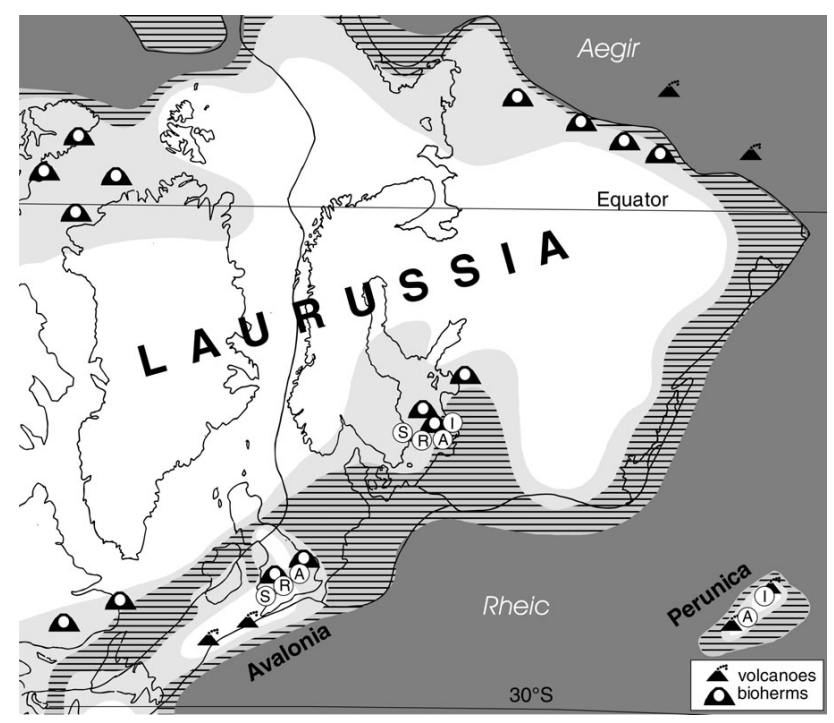

Figure 10. Palaeogeography of eastern Laurussia in the mid-Silurian (Wenlock, $425 \mathrm{Ma}$ ) and adjacent Perunica (Bohemia) with distribution of some discinoid genera (after Cocks \& Torsvik 2005, modified). A - Acrosaccus, I - Ivanothele, $\mathrm{R}$ - Rugadiscina, S - Schizocrania.

resting on the bottom of a clearly defined depression. The listrium is almost flat, with broad outer listrial plates and probably with a weakly or non-mineralised axial part. The surface of the outer listrial plates is covered by prominent transverse growth lines. The ventral valve interior is devoid of well-defined muscle impressions.

The surface of the dorsal valve is densely covered by prominent, unevenly sized growth fila. Concentric lamellae are absent but some coarser growth file may correspond to breaks in the shell growth. The ornament becomes progressively coarser with shell size. The ornament of the ventral valve is different. There are prominent concentric rugellae arranged at regular distances, separated by concave interspaces having very fine growth lines. Rugellae are high, thin, slightly inclined toward periphery of the shell. There are 5 or 6 rugellae per $5 \mathrm{~mm}$ anteromedianly. Microornament has not been examined.

Remarks. - The new species differs from Rugadiscina rugata (J. de C. Sowerby, 1839) by absence of rugellae on the dorsal valve exterior, and a longer pedicle track with larger outer listrial plates. Both species are also of different age: Rugadiscina rugata occurs in slightly younger strata (Ludfordian) in Britain. The specimens from Gotland occur in strata of Gorstian age, with nearly all occurrences restricted to the Hemse Formation. However, two specimens, both ventral valves attached to a bivalve shell, are known from the lower Ludfordian (Burgsvik Formation) of Gotland (Fig. 9O). Because the morphology of the dorsal valve of these specimens is unknown, they may belong to the new species or to $R$. rugata.
Distribution. - Ludlow, Gorstian, Hemse Formation, Petesvik (Hablingbo sn.); Ludfordian, Burgsvik Formation, Burgsvik.

\section{Rugadiscina sp. \\ Figure 9P, R}

Material. - One ventral valve: NRM-PZ Br 23920.

Description. - The valve is weakly concave, circular in outline, $14 \mathrm{~mm}$ wide. The apex is subcentral. Pedicle track is deep, spindle shaped, occupying two-thirds of the postapical part of valve. The pedicle track is narrow, resting in a deep, slit like depression. Listrium is unknown. Ornament of the valve consists of distinct elevated concentric rugellae, more densely arranged near shell periphery.

Remarks. - The ventral valve is squeezed inside the slightly larger dorsal valve which is preserved as only a narrow peripheral strip, indicating that the ventral valve was inserted inside a somewhat larger dorsal valve in the living animal. The shell is similar to Rugadiscina petesviki sp. nov., but differs by its larger size, narrower and posteriorly tapering pedicle track and strikingly narrower outer listrial plates, which are broad, planar and widest at about midlength of the pedicle track in $R$. petesviki.

Distribution. - Wenlock, Sheinwoodian, Upper Visby Formation, Gnisvärd (Tofta sn.).

\section{Conclusion}

Current palaeogeographical reconstructions (e.g. Cocks \& Torsvik 2002, 2005) locate the Silurian of Gotland, England and Wales, and Bohemia in a subtropical belt. It is natural that similar subtropical palaeolatitude and shallow marine palaeoenvironments were colonised by similar sets of benthic communities and their particular taxa are closely related (Boucot 1985). Therefore it is not surprising, that discinids known from the Welsh Borderlands and Gotland are the same or very closely related. That is particularly the case for Schizocrania striata (J. de C. Sowerby, 1839) and Schizocrania verneuilii (Davidson, 1848). Geographic extension of Schizocrania is undoubtedly related to its mode of life. Living adult specimens attached to empty cephalopod shells can easily drift over a great distance (Lockley \& Antia 1980). Schizocrania is unknown in the Silurian of Bohemia. A plausible explanation for this may include some form of oceanic and/or current barrier and lack of significant siliciclastic admixture in the shallow-water Silurian sediments in Bohemia.

Discinids are dependent on the accessibility to hard substrates for settlement during their pelagic stage, in the 
same way as their extant relatives (Mergl 2010). Extant discinids have a long planktotrophic pelagic developmental stage (Lüter 2001) which should also be indicated in their Palaeozoic ancestors. One could speculate that between hatching and settlement, the pelagic stages (= larva and "pelagic juveniles") could disperse over great distances. Their drift along shelves of Laurussia towards docking Avalonia in Silurian can explain the close affinity of some Gotland and British species (Cocks \& Torsvik 2005). Some British species [Acrosaccus cocksi Mergl, 2006, and Orbiculoidea forbesii (Davidson, 1848)] occur in Gotland, but other taxa appear to be endemic to Gotland (Acrosaccus barabackenis sp. nov., Acrosaccus hallaensis sp. nov.) or the Welsh Borderlands (Acrosaccus woolhopensis Mergl, 2006, Schizotreta walkeri Mergl, 2006).

Faunal differences between Gotland and Bohemia are striking. They are probably related to the greater distance between Laurussia and Perunica (Bohemia) and the existence of an oceanic barrier (Fig. 10) (Cocks \& Torsvik 2005). Occasional overriding of this barrier by pelagic stages of discinids was followed by peripatric speciation, and due to the interruption of gene flow, by origination of different but related species ( $c f$. Kř́iž 2007, 2008; Manda 2008). The only closely related species are Ivanothele pilidium (Lindström, 1861) and I. mordor Mergl, 1996, both are of Ludlow age. Ivanothele Mergl, 1996, and its Devonian relative Chynithele Havlíček, 1996 are discinids with a preference for shallow-water biostromes, having shells clinching in coral tufts. Additional differences in the composition of discinoid faunas between Gotland, the Welsh Borderland, and Bohemia is thus likely dependant on three factors:

1. Heterochroneity of occurrences of closely related species: for example, Rugadiscina petesviki sp. nov. and R. rugata (J. de C. Sowerby, 1839). The range of the latter species is Ludfordian in Britain, but Gorstian in the Gotland species. The specimens of Rugadiscina of Ludfordian age from Gotland are not sufficiently well preserved to confirm their identity as $R$. rugata.

2. Requirements for settling of larvae: there were differences in substrate conditions, depths, and food accessibility between Gotland and the Welsh Borderlands at the same time and presence or absence of the species is simply ecological. The absence of marly sedimentation in Bohemia is significant.

3. Collection bias: discinoid brachiopods are relatively minor faunal elements and cannot be used as index species. Because they are generally rare compared with other shelly fossils, samples are restricted to a few, often poorly preserved, specimens. Former authors (Barrande 1879, Hedström 1910, Hede 1921) generalised their finds referring them to any known species, for instance to Discina forbesii Davidson, 1848 or Orbiculoidea rugata (J. de C. Sowerby, 1839). In contrast to other Silurian brachiopod groups (e.g. atrypids) it is impossible to collect large samples of discinids in the field.

\section{Acknowledgements}

The author is greatly indebted to Christina Franzén, Jan Bergström and Jonas Hagström from the Swedish Museum of Natural History, Stockholm for kind invitation, access to brachiopod collections, significant discussion about stratigraphical and locality data, and technical support which were crucial for a research; to Jana Nebesářová and J. Vaněček, from Academy of Science of the Czech Republic, České Budějovice for access of SEM work; to Glenn A. Brock and Arthur J. Boucot for reviews and comments which significantly improved the work. This study was supported by a grant of the Grant Agency of the Czech Republic GAČR 205/07/0466: Origin and evolution of the discinoid brachiopods in the Palaeozoic.

\section{References}

ALDRIDGE, R.J., Siveter, DAVID J., SiVETER, DEREK J., LANE, P.D., PALMER, D. \& WoOdCOCK, N.H. 2000. British Silurian Stratigraphy. 542 pp. Joint Nature Conservation Committee, Peterborough.

BARRANDE, J. 1879. Systême silurien du Centre de la Bohême. $I^{\text {ère }}$ partie: Recherches Paléontologiques. Volume 5. Classe des Mollusques. Ordre des Brachiopodes. 226 pp. Prague \& Paris.

BASSETT, M.G. \& COCKS, L.R.M. 1974. A review of Silurian articulate brachiopods of Gotland. Fossils and Strata 3, 1-56.

BLAKE, J.F. 1902. List of the types and figured specimens recognised by C.D. Sherbern, F.G.S., in the collection of the Geological Society of London. London Geological Society.

BouCOT, A.J. 1975. Evolution and extinction rate controls. 427 pp. Elsevier. Balkema.

Boucot, A.J., Rowell, A.J., Racheboeuf, P., Pereira, E., GonÇAlves DE MElo, J.H. \& PEIXOTO DE SiQueIRA, L. 2001. Position of the Malvinokaffric Realm's northern boundary (Early Devonian) based on newly discovered brachiopods from the Parecis Basin (Brazil). Journal of the Czech Geological Society 46, 109-120.

ClARKE, J.M. 1913. Fósseis devonianos do Paraná. Monographias do Servico Geologico e Mineralogico do Brasil I, 1-353.

CocKS, L.R.M. 1978. A review of the British Lower Palaeozoic brachiopods, including a synoptic revision of Davidson's Monograph. Monograph of the Palaeontographical Society London 549, part of vol. 131 for 1977, 1-256.

COCKS, L.R.M. \& TORSVIK, T.H. 2002. Earth geography from 500 to 400 millions years ago: a faunal and palaeomagnetic overview. Journal of the Geological Society, London 159, 631-644. DOI 10.1144/0016-764901-118

COCKS, L.R.M. \& TORSVIK, T.H. 2005. Baltica from the late Precambrian to mid-Palaeozoic times: The gain and loss of a terrane's identity. Earth-Science Reviews 72, 39-66.

DO1 10.1016/j.earscirev.2005.04.001

COPPER, P. 2004. Silurian (Late Llandovery-Ludlow) Atrypid Brachiopods from Gotland, Sweden, and the Welsh Borderlands, Great Britain. 215 pp. National Research Council Research Press, Ottawa, Ontario.

DAVIDSON, T. 1848. Mémoire sur les brachiopodes du Système silurien supérieur de l'Angleterre. Bulletin de la Société géologique de France, série 2, 5, 309-338, 370-374.

DAVIDSON, T. 1866. A monograph of the British fossil Brachiopoda. Part. VII, No. I. The Silurian Brachiopoda. Mono- 
graph of the Palaeontographical Society, London 19 (for 1865), $1-88$.

GRAY, J.E. 1840. Synopsis of the contents of the British Museum. $42^{\text {th }}$ edition. 370 pp. British Museum, London.

HALL, J. 1847. Palaeontology of New York, vol. 1. Containing descriptions of organic remains of the lower division of the New-York System. 338 pp. Charles van Benthuysen, New York.

HAVLÍČEK, V. 1972. Life habits of some Ordovician inarticulate brachiopods. Věstník Ústředního ústavu geologického 47, 229-233.

HAVLÍČEK, V. 1994. Kosovian inarticulate brachiopods and their ancestors (Late Ordovician, Prague Basin). Věstník Českého geologického ústavu 69, 59-68.

HAVLÍČEK, V. \& VANĚK, J. 1996. Brachiopods and trilobites in the Chýnice Limestone (Emsian) at Bubovice (Čeřinka hillside; Prague Basin). Palaeontologica Bohemiae 2, 1-16.

HEDE, J.E. 1921. Gottlands Silurstratigrafii. Sveriges Geologiska Undersökning C305, 1-100.

HEDSTRÖM, H. 1910. The Stratigraphy of the Silurian strata of the Visby district. Geologiska Föreningens i Förhandlingar 32, $1455-1484$.

HoEL, O.A. 2005. Silurian Leptaenidae /Brachiopoda) from Gotland, Sweden. Paläontologische Zeitschrift 79(2), 263-264.

HoEL, O.A. 2007. Cementing strophomenide brachiopods from the Silurian of Gotland (Sweden): Morphology and life habits. Geobios 40(5), 589-608. DO1 10.1016/j.geobios.2006.08.003

HOLLAND, C.H., LAWSON, N.J.D. \& WALMSLEY, V.G. 1963. The Silurian rocks of the Ludlow district, Shropshire. Bulletin of the British Museum (Natural History), Geology 8, 93-171.

HOLMER, L.E. \& POPOV, L.E. 2000. Lingulata, 30-46. In WILLIAMS, A., BRUNTON, C.H.C. \& CARLSON, S.J. (eds) Treatise on Invertebrate Paleontology, part $\mathrm{H}$, Brachiopoda, Revised, Volume 2: Linguliformea, Craniiformea, and Rhynchonelliformea (part). i-xxx, 423 pp. Geological Society of America \& University of Kansas, Boulder \& Lawrence.

KŘíŽ, J. 2007. Origin, evolution and classification of the new superorder Nepiomorphia (Mollusca, Bivalvia, Lower Paleozoic). Palaeontology 50(6), 1341-1365. DO1 $10.1111 / \mathrm{j} .1475-4983.2007 .00720 . \mathrm{x}$

KŘİ̌̌, J. 2008. Algerina gen. nov. (Bivalvia, Nepiomorphia) from the Silurian of the North Gondwana margin (Algeria), peri-Gondwanan Europe (France, Italy), Perunica (Prague Basin, Bohemia) and the Siberian Plate (Tajmyr Basin, Russia). Bulletin of Geosciences 83(1), 79-84. DOI 10.3140/bull.geosci.2008.01.079

LAUFELD, S. 1974. Reference localities for palaeontology and geology in the Silurian of Gotland. Sveriges Geologiska Undersökning C705, 1-172.

LINDSTRÖM, G. 1861. Bidrag till kännedomen om Gotlands brachiopoder. Öfversigt af Kungliga Vetenskaakademiens Förhanhandlingar Stockholm 17, 337-380.

LOCKLEY, M.G. \& ANTIA, D.D.J. 1980. Anomalous occurrences of the Lower Palaeozoic brachiopod Schizocrania. Palaeontology 23(3), 707-713.

LÜTER, C. 2001. Brachiopod larval setae - a key to the phylum's ancestral life cycle?, 46-55. In BRUNTON, C.H.C., COCKS, L.R.M. \& LoNG, S.L. (eds) Brachiopods Past and Present. Taylor \& Francis, London \& New York.

MANDA, Š. 2008. Palaeoecology and palaeogeographic relations of the Silurian phragmoceratids (Nautiloidea, Cephalopoda) of the Prague Basin (Bohemia). Bulletin of Geosciences 83(1), 39-62. DOI 10.3140/bull.geosci.2008.01.039

MERGL, M. 1996. Discinid brachiopods from the Kopanina Formation (Silurian) of Amerika quarries near Mořina, Barrandian, Central Bohemia. Časopis Národního muzea, $\check{R} a d a$ př́rodovědná 165(1-4), 121-126.

MERGL, M. 2001. Lingulate brachiopods of the Silurian and Devonian of the Barrandian. Acta Musei nationalis Pragae, Series B - historia naturalis 57, 1-49.

MERGL, M. 2006. A review of Silurian discinoids brachiopods from historical British localities. Bulletin of Geosciences 81(4), 215-236. DOI 10.3140/bull.geosci.2006.04.215

MerGL, M. 2008. Lingulate brachiopods from the Acanthopyge Limestone (Eifelian) of the Barrandian. Bulletin of Geosciences 83(3), 281-298. DOI 10.3140/bull.geosci.2008.03.281

MERGL, M. 2010. Discinid brachiopod life assemblages: Fossil and extant. Bulletin of Geosciences 85(1), 27-38. DO1 10.3140/bull.geosci.1161

MERGL, M. \& FERROVÁ, L. 2009. Lingulate brachiopods from the Chýnice Limestone (upper Emsian, Barrandian; Czech Republic. Bulletin of Geosciences 84(3), 525-546. DO1 $10.3140 /$ bull.geosci.1143

MERGL, M. \& MASSA, D. 2005. A new giant discinoid brachiopod from the Lower Devonian of Algeria. Acta Palaeontologica Polonica 50(2), 397-402.

MURCHISON, R.I. 1839. The Silurian System, founded on geological researches in the counties of Salop, Hereford, Radnor, Montgomery, Caermarthen, Brecon, Pembroke, Monmouth, Gloucester, Worcester, and Stafford; with descriptions of the coalfields and overlying formations. i-xxxii, $768 \mathrm{pp}$. John Murray, London.

MURCHISON, R.I. 1854-72. Siluria. The History of the oldest known rocks containing organic remains, with a brief rescription of the distribution of gold over the Earth. i-xvi, $1-523$, pls $1-37$ ( $3^{\text {rd }}$ ed., $1859 ; 4^{\text {th }}$ ed., $1867 ; 5^{\text {th }}$ ed. 1872$)$.

MUSTEIKIS, P. \& COCKS, L.R.M. 2004. Strophomenide and orthotetide Silurian brachiopods from the Baltic region, with particular reference to Lithuanian boreholes. Acta Palaeontologica Polonica 49(3), 455-482.

D'ORBIGNY, A. 1847. Considérations zoologiques et géologiques sur les Brachiopodes ou Palliobranches. Comptes Rendus Hebdomadaires des Séances de l'Académie des Sciences 25, 193-195, 266-269.

ROWELL, A.J. 1965. Inarticulata, H260-H269. In MOORE, R.C (ed.) Treatise on Invertebrate Paleontology, part $\mathrm{H}$, Brachiopoda, Volume 1. Geological Society of America and University of Kansas Press, Boulder, Colorado \& Lawrence.

SCHUCHERT, C. 1893. Classification of the Brachiopoda. American Geologist 11, 141-167.

WaAgen, W. 1885. Salt Range fossils, I. Productus-Limestone fossils, Brachiopoda. Memoirs of the Geological Survey of India, Palaeontologia Indica (series 13) 4(5), 729-770.

WILLARD, B. 1928. The brachiopods of the Ottosee and Holston formations of Tennessee and Virginia. Bulletin of the Harvard Museum of Comparative Zoology 68, 255-292.

Williams, A., BRUNTON, C.H.C. \& CARLSON, S.J. (eds) 1997. Treatise on Invertebrate Paleontology, part H, Brachiopoda, Revised, Volume 1: Introduction. i-xx, 539 pp. Geological Society of America, University of Kansas, Boulder \& Lawrence. 